\title{
Research on Physical Education Teaching of Confucius
}

\author{
Zhenhua Guo ${ }^{1, a^{*}}$, Jun Yang ${ }^{1, b}$ and Meirong Tang ${ }^{1, c}$ \\ ${ }^{1}$ College of Sports Science, Jishou University, Renmin South Road 120, Jishou City Hunan Province, \\ China

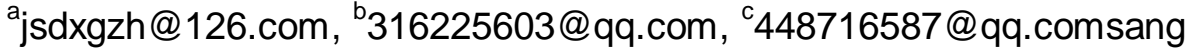 \\ * The corresponding author
}

Keywords: Confucius; Sports teaching; Sports thought; Spring and Autumn period

\begin{abstract}
Confucius was the most influential educator in spring and autumn period, also was the first t educator who put forward sports thoughts. For more than 40 years of teaching practice, he not only proposed the sports thought and concept of preserve one's health, but also it contained rich and colorful sports content and teaching methods. This paper, using the literatures logical reasoning and other research methods, on the basis of Confucius education thought, teacher's teaching methods are discussed from the following the aspects: Advocating the heuristic teaching; Teaching students in accordance of their aptitude; Teaching students by personal example as well as verbal instruction; Paying to learning and teaching method; Edutainment; Making no social distinctions in teaching; Accepting the opinions of the education object; Cultivating the students interest and so on. The learning methods are analyzed from the following aspects: Attaching great importance to be practical and realistic, encouraged to choose and learn from the good; Feeling not ashamed to learn from one's subordinates; Being insatiable in learning and so on. These teaching and learning method reflect the simple dialectic and materialism point of view, which are the part of the essence, of Confucius in the sports teaching and precious heritage, have a profound impact on the development of modern sports and the ancient sports.
\end{abstract}

\section{Introduction}

Confucius was the most influential educator in spring and autumn period, also was the first educator who put forward sports thoughts. Starting around thirty years old or so, until seventy-three years (479 BC) before he died, he had always persisted in teaching. For more than 40 years of teaching practice, he not only proposed the sports thought and concept of preserve one's health, but also it contained rich and colorful sports content and teaching methods. These teaching and learning method reflect the simple dialectic and materialism point of view, which are the part of the essence, of Confucius in the sports teaching and precious heritage, have a profound impact on the development of modern sports and the ancient sports.

\section{The Time Background of Confucius on Pe Teaching}

After entering the class society, the human military sports occupied very important position and larger proportion, which were the same on school education in the slave society between east and west. During the spring and autumn period, and the wars between the marquis often happened. The rulers needed the talented persons who were accomplished with both the pen and the sword could run the world. Therefore, "the scholars" during the spring and autumn period still give priority to samurai education and military skills training was necessary. Due to the demand of the society, the purpose of Confucius set up the private school was to cultivate the talents who mastered military skills and martial arts. so to speak, Confucius is composed with the content of sports education in the teaching, which was the necessity of era demand and personal ambition. 


\section{The Physical Education Aching Conditions that Confucius Himself Owned}

Confucius was a descendant of the Yin people, who had rich customs that worshiped martial arts. Confucius' ancestors were nobles of Song guo, who mastered political and military power. Later, they moved into Luguo. Confucius' father named Su Liangqi, who was a warrior and had won several battle achievements. According to historical records, he could lift the city gate and was famous for his courage and strength among the dukes. According to< Records of the Grand Historian>, Confucius was tall, "Others felt he was very different because of his tall body." Although he claimed to "he war very poor when he was young", but as a member of the "noble" classes, his military education was strict and comprehensive. Mr Tong ShuYe pointed out: "Confucius and his father were famous for their strength and were real warriors." <Mister Lv's Spring and Autumn Annals > recorded: "Confucius' strength was very great, he could lift the gates." According to <Huai Nan Tzu>, Confucius was both brave and resourceful, and also was adept with both the pen and the sword. Due to the education of Confucius and his superhuman skills, he the condition and ability to teach his students " Liu Yi" and teach them according to their aptitude.

\section{The Teaching Achievements of Confucius}

According to the historical recorded, Confucius had three thousand disciples, because Confucius was good at teach his disciples according to their aptitude, seventy-two of his disciples were proficient in "Six Yi". Confucius' student zi lu was a valiant soldier. He could dance Qan Qi dance without eating something for seven days. Confucius toured the various countries with his disciples. When they passed through Pu Guo, they were blocked by the people from Pu Guo. His disciple Gong Liangru, who has great strength, drew out his sword and fought with the offenders, which make them fear and ran away. Ran You, a disciple of Confucius, was versed in both literature and military affairs, and versatile. $<$ Zuo Zhuan> recorded him "He fought with Qi army with his spear ", he had a great achievement. The Student of Confucius were prominent in the world because of their the military ability and brave, which were inseparable.to that Confucius attached great importance to the imperial armaments and military martial arts teaching.

Six Arts. Confucius had a clear concept of armament. Confucius advocated "Rely on good man to teach the people for seven years, and the people are able to contact the arms." In the teaching, Confucius paid attention to the cultivation of both the military knowledge and military technology. The teaching content of Confucius basically followed the education content of the Western Zhou Dynasty. The purpose of education was to practice martial arts and learn "etiquette". Confucius advocated " Be proficient in arts". Arts essentially refers to the "six arts", namely, shot, books, music, etiquette, mathematics, drive. And music, drive and shot belong to military sports. "Shot" means archery. Drive means to drive a carriage. On Shang and Zhou Dynasties and the spring and autumn period, the chariot battle was the main way of the war. The soldiers on the carriage must be good at shot and driving a carriage. So, "shot" and "drive" were indispensable military technology, especially, for the aristocracy. The aristocracy worshiped martial arts. Practice martial arts was required for all nobles to learn at an early age. And learning the technology and skills that took part in the war and guide the war was the required course too. So, "shot" and "drive" became the required military physical education course for them after entering the school.Music dances in the dancing required specialized training, containing the content and meaning of physical education. Music dance, according to its content and dance props, cultural dance and martial arts dance. "Learn Gan and Ge in spring and summer." Martial arts dance is one dance of holding Gan and Ge, which was the combination of martial arts and dance. From the detailed explanation about Big Martial Arts Dance written in the book of Shih Chi, we can learn that Big Martial Arts Dance included a lot of action about hit and gill. Whether cultural dance or martial arts dance must demand systematic training. The demands for the agility, flexibility, coordination, power must contain the factors and contents of physical education. In the practical courses, Confucius taught his disciples the fearless and the indomitable spirit. And in the long-term practice of teaching, 
Confucius constantly tried to improve the teaching contents, teaching methods and made the teaching contents variety and vividness, aims to cultivate the students' all-round development.

TheTraditional Chinese Body-Building. During the spring and autumn period, due to the opening of thought and the social civilization progress, the traditional Chinese body-building thought and guidance came into being. In the process of teaching, Confucius not only implanted body-building ideals in students, but also taught them body-building methods, and paid attention to personally practice. Confucius advocated that "quiet" could make people's longevity, which was the thought characteristics of keeping somebody in good health and had considerable influence on the body-building thought of Dao, medical, Buddhism and so on later. Confucius' thought and practice activities was noticeable for the students' education and guidance, which was one important part of Confucius' physical education.

Entertainment Activities. Entertainment activities belong to the part of physical exercise in the concept of modern sports. Confucius considers that the fitness entertainment can be used for body-building, in addition, what's more important is it can maintain one's temperament and cultivate one's body and mind. So Confucius's entertainment content was very rich. Confucius liked fishing and hunting. His skill was also very great. And Confucius didn't care about the gain, but paid attention to these activities' entertaining very much. Mountain climbing and outing were and the frequent activities of Confucius' physical education teaching. Confucius often climbed the mountain with his students and took mountain climbing as a beneficial activity for the body and mind health.

"Courage" Is One of the Contents of Confucius' Physical Education. "Courage " mainly refers to brave, generally, one kind of spirit and quality, including the physically strong, the ability to brave behavior and improvisation. Confucius thought courage was constrained by etiquette and regulated certain moral norms. As a person is brave, and if he is not accepting the constraints, he will keep the offence of insurrection. Gentleman has only courage and has no justice, he will make some trouble and rebel; A base person has only courage and has no justice, he will become a robber. Confucius referred to " couragemany times in <The Analects of Confucius>, such as "The courageous are free from fear ", "A moral person must be courageous" According to the requirements of Confucius, "courage" must be implemented in action. One person should not only have a strong body, but also master certain skills.

\section{The Physical Education Teaching Methods of Confucius}

Confucius' Teaching Methods. Teaching Students According to Their Aptitude. During the teaching of physical education, Confucius, on the basis of understanding his students' general character, made the comprehensive analysis about individual differences of his students, and then he took the different teaching methods according to the differences of students' mental characteristics. Confucius was fond of watching and understanding students, that is, to watch what his students had done, and understood what his students had experienced, as well as the students' interests. Confucius not only inspected his students' private behavior after class, fully grasped the characteristics and actual situation of the students, and then taught them according to their different personality traits. Rather than adopt the same sermon. In addition, students' ability and IQ were not the same. He used some different approaches to teach his students. Student had commons in the physical and psychological aspects, and shew some individual differences about physical condition, personality characteristics, psychological quality. Confucius thought that teaching students should base the teaching contents on their aptitude. Let some students neither "digest" nor "hungry". He said:"Can tell the students above medium level profound knowledge. Can't tell the students below the medium level profound knowledge."

Advocating the Heuristic Teaching. In the history of the world education development, the man who first proposed heuristic teaching is Confucius. Heuristic education is the one big characteristic of Confucius' physical education teaching method. In the process of heuristic teaching, Confucius was very good at using the method of "knocking its ends". That is to say, from the pros and cons to inspire and lead student, cause the students to widen our sight and get conclusion from the comparison and 
analysis. In short, Confucius thought when the student have no subjective need, the teacher needn't teach him. When the student can not comprehend by analogy, the teacher needn't teach him. So, Confucius' heuristic teaching, first of all, pay attention to students "needs". At the same time, take the students' thinking activity as the center of the heuristic teaching content. These two points are the essential part that we understand and master the heuristic teaching.

Paying to Learning and Teaching Method, Edutainment, Making No Social Distinctions in Teaching. Regard to learning and teaching method, Confucius has many popular comments on " pleasure ". " When studies custom it, not also said!" , "learning and the learning of the time." Confucius not only attaches importance to the happiness of learning, but also has a lot of comprehension about the pleasure of the teachers' teaching. "to be insatiable in learning, to be tireless in teaching" is the goal of Confucius lifelong practice. Confucius once said: "Know its rather know, like to know rather happy know", which divides the realm of learning and teaching into three different levels of "knowing it, liking it and enjoy it" which full reflects the importance of internal reason. The practice of physical education on edutainment is being learnt and studied by the educators in different countries, which has very important significance for the current school physical education.

Listening to the Opinions of the Students Humbly. Confucius, in the teaching process, often discussed the questions with his disciples qually. In addition, Confucius asked his disciples to help him to improve some practices. For example, his student $\mathrm{Zi} \mathrm{lu}$ often put forward the blunt criticism towards him. Confucius accepted his opinion. Throughout the analysis above, Confucius " is good at teaching ", which truly reflects the successes and uniqueness of . Confucius on cultivating talents.

The Learning Methods of Students. Advocating "to Be Insatiable in Learning", "Learning and the Learning of the Time.". In the process of learning, there is no shortcut. Only working hard can truly achieve the goal of learning. Confucius said: "I am not born wise or learned. I am be fond of ancient culture, and pursue diligently." Confucius told the students with own experience: Must be industrious. In addition, pay attention to methods in the process of learning. At first, Confucius said: "You can think of, I can do." Learning is a process of accumulation. That constantly review what has been learned from which, one can extract some new knowledge and wisdom, and lay a good foundation. for further study. Secondly, Confucius said: learning is like a vast sea. The knowledge we learned is just one part of them. When choosing the learning content, should have a clear purpose. Only spend the limited time and energy in learning the purposeful contents, can achieve the good effect.

Pay Equal Attention to Learning and Tought. Confucius realized the dialectical relationship between the learning and the thought. He said:"Learning without thought is confused; thought without learning gets nothing."He thought:"Once I do not eat all day long, not sleep all night, thinking problem, (but) no benefit, (so) as well to learn. At the same time, he also attached great importance to the development thinking, emphasizes the thinking, put forward the gentleman had nine things to think about. He was not satisfied with the students without serious thinking .

Advocating "One Should Be Fond of Learning and not Feel Ashamed to Ask and Learn of His Inferiors.". Everyone is limited by time and space, could not have a direct experience of everything, so asking others becomes an important method of learning knowledge. Confucius is a person who is good at "asking question". Influenced by Confucius, his disciples took "asking question" as a sign of studying hard. However, asking question can be divided into "asking questions from one's subordinates" and "asking questions from higher authorities ". It is not easy for one to asking questions from one's subordinates. In the society that identity and status were very strict, knowledge was regarded as an symbol of identity. That the cultured people counseled to the man who has little talent and learning often was laughed at. Therefore, Confucius advocated " One should be fond of learning and not feel ashamed to ask and learn of his inferiors" is a challenge and breakthrough to social hierarchy. This not only needed knowledge, but also needed more courage. 


\section{Acknowledgment}

The National social Science Fund (12BTY046); 2015Philosophy and Social Science Fund Project of Hunan province (15YBA318); 2015Scientific Research Key project of Hunan Province Department of Education (15A154); 2015Western philosophy and Social science Fund project of Hunan province (15YBX037); 2014 Core Curriculum group ConstructionProjects of General Class of Jishou University (jdtshxkc201403).

\section{References}

[1] Fu Yangnong. The Analysis of Confucius Physical Education Concept and Practice [J], Journal of Yantai Teachers College, Vol.1,1997, pp.84-89.

[2] Wang Yu-xun, The Study and Evaluation on Teaching Methods and Characteristics of Confucius [J], Journal of Linyi Teachers' University, Vol. 28 No.2, 2006, pp.31-35.

[3] Hao Huifang, OnTeaching methodsfrom the Analects of Confucius [J], Chuanshan Journal, Vol.3, 2007, pp.113-115.

[4] Qi Guoqing, The Revelation for the Contemporary Physical Education and its Application of Confucius Education Thought of "Six Arts" [J]. China's school education, Vol.4, 2014, pp. 4.

[5] Confucius, Confucius [M], Chongqing:Southwest Norma University Press, 1995.

[6] Confucius, the Analects of Confucius [M], Changsha, Yuelu press, 2000.

[7] Yang Baiyun, The Discussion of Confucius Teaching Methods[J], Vol.12, pp.37.

[8] WANG Yu-xun, The Study and Evaluation on Teaching Methods and Characteristics of Confucius [J], Journal of Linyi Teachers'University, Vol.28, 2006, pp.30-35.

[9] Jia Mingjie, On the Practicability of Confucius' Teaching Methods [J], Journal of Baotou Vocational and Technical College, Vol.12, 2011, pp.30-33.

[10] Hu Xu, Hao Yan-pin, Han Wei, Discussion on Confucius'Thought Physical Educationof and Its Practices [J], Journal of Yanan University (Natural Science Edition), Vol.29, pp.102-105. 